\title{
Výchova k udržitelnému rozvoji: mýtus nebo nová vlna?
}

\author{
Jan Činčera
}

Envigogika 2008/III/1 - Recenzované články/ Reviewed Papers

Publikováno/Published 21. 05. 2008

DOI: http://dx.doi.org/10.14712/18023061.25

\begin{abstract}
Abstrakt:
Článek porovnává různé pohledy odborné komunity na problematiku výchovy k udržitelnému rozvoji.

Ačkoli pojem výchova $k$ udržitelnému rozvoji (VUR) je prosazován již více než patnáct let, stále otevírá $v$ odborné komunitě široké pole možných interpretací. Částí odborné komunity je odmítána samotná myšlenka udržitelnosti, další odborníci zpochybňují reálný prínos konceptu do výchovně vzdělávací praxe. Ve druhé části článek stručně sumarizuje a srovnává hlavní principy dvou různých př́stupů k VUR: první, který VUR definuje jako pluralistickou tradici environmentální výchovy, a druhý - radikálně transformativní přistup volající po paradigmatické změně v celém vzdělávacím kontextu.
\end{abstract}

\section{Klíčová slova:}

Vzdělávání pro udržitelný rozvoj, environmentální vzdělávání, pluralitní tradice, sloganové systémy, udržitelné vzdělávání

\begin{abstract}
:
Although the term 'education for sustainable development' (ESD) was launched more than 15 years ago, it is still interpreted in widely differing ways. One part of the scientific community avoids the concept of sustainability, others discuss whether any changes have been launched in the educational field resulting from the new concept. The article goes on to briefly summarize and contrast two different approaches in ESD, the first which defines ESD as a pluralistic tradition of environmental education and the concept of radical transformative approach calling for a paradigmatic shift in the whole educational environment.
\end{abstract}

\section{Key words:}

Education for sustainable development, environmental education, pluralist tradition, slogan systems, sustainable education 


\section{Úvod}

V návaznosti na Konferenci OSN o životním prostředí a rozvoji v Rio de Janeiro začaly vládní organizace jednotlivých zemí odpovědné za životní prostředí do svých koncepčních dokumentů a politik prosazovat myšlenku výchovy k udržitelnému rozvoji jako "vizi výchovy, která usiluje o rovnováhu lidského a ekonomického blahobytu s kulturními tradicemi a respektem pro př́rodní zdroje Země" (UNESCO, 2004). Podle Mckeown tak "na rozdíl od většiny výchovně vzdělávacích hnutí byla výchova k udržitelném rozvoji iniciována lidmi nepocházejícími z pedagogické komunity... Koncept a obsah výchovy k udržitelnému rozvoji ... je rozvíjen ministerstvy, např. životního prostředí či zdraví, a je předáván pedagogickým pracovníkưm k dalšímu šiření." (McKeown, 2002)

Jakým způsobem na tento přístup odborná komunita působící v oblasti environmentální výchovy reaguje? Cílem článku je upozornit na nejednoznačnost v přijetí i chápání tohoto přístupu, které kolísá od jeho naprostého odmítnutí až po bezvýhradné přijetí.

\section{Nová nálepka, špatný obsah}

Kritika konceptu výchovy k udržitelnému rozvoji souvisí bud’ s odmítnutím konceptu udržitelného rozvoje jako takového nebo s kritikou výchovy podřizené určitému ideologickému konceptu. Představitelem prvního názoru je např. van Matre (2005). $V$ předmluvě k Rangers of the Earth upozorňuje na antropocentrický charakter konceptu, připomíná námitky proti možnosti "udržitelně růst" a shrnuje: "V krátkosti, pokud by lidé věděli, co udržitelnost opravdu znamená, nelíbilo by se jim to. Musíme chtít po lidech, aby udělali ve svém životě větši změny... Často se mě po přednáškách ptají: "Chcete tím říct, že se máme vrátit zpátky?" Dobrotivý Bože, ano. Jediná otázka je jak daleko, rychle a co si s sebou můžeme vzít." (p.14) Van Matreho výchova o Zemi programově neodkazuje na koncept udržitelnosti, ale na hlubinně ekologický a biocentrický proud environmentálního myšlení.

Druhý z důvodů proti výchově k udržitelnému rozvoji reprezentuje např. Milton McClaren, podle kterého by výchova neměla být ř́zena žádným konkrétním politickým programem, měla by zůstat antiideologickou a paidocentrickou: "Výchova je ve své podstatě antiideologická. Není pro žádný specifický program. Naopak, cílem výchovy je umožnit lidem chovat se inteligentně, vážit alternativy, moudře volit a vytvářet možnosti, které mohly zůstat opomenuty. Jestliže nazveme environmentální výchovu výchovou k environmentalismu, potom zmateme její cíl a zvrátíme ji k indoktrinaci. " (McClaren, 1993).

\section{Nová nálepka, starý obsah}

S jiným pohledem přichází Ian Robottom, který kriticky posuzuje reálné změny, které koncept výchovy k udržitelnému rozvoji (ESD) přinesl ve srovnání s dosavadním konceptem environmentální výchovy (Robottom, 2007). Ve své analýze upozorňuje na symbolickou rovinou každé vzdělávací reformy: staré definice a pojmy jsou nahrazeny novými, staré metodiky jsou zkritizovány. Nová terminologie ještě sama o sobě ale nezajistí reálné změny ve školách. Podle jeho názoru představuje současný trend "agresivního a extenzivního přenálepkování environmentální výchovy výchovou $k$ udržitelnému rozvoji" především náhradu jednoho sloganového systému za jiný. Podle Robottoma je jako jeden z důvodů pro prosazování nového konceptu používán argument, že praxe environmentální výchovy nedostatečně zohledňovala sociální a ekonomické aspekty environmentálních problémů, které by proto měly být $v$ novém pojetí výchovy silněji zastoupeny. Oba aspekty jsou ale $\vee$ Tbiliské definici environmentální výchovy (1977) zahrnuty: "posílit naše vědomí a porozumění ekonomické, sociální a ekologické provázanosti". Argument o potřebě nahradit environmentální výchovu 
výchovou k udržitelnému rozvoji tedy "vychází ze srovnání jazyka ESD s praxí environmentální výchovy."

Robottom upozorňuje na značnou podobnost definic environmentální výchovy a výchovy k udržitelnému rozvoji a na fakt, že tak jako „environmentální výchova mưže být interpretována několika způsoby (zahrnující výchovu o, v a pro životní prostredí), může být slogan ESD interpretován jako podpora kterékoliv či všech svých dimenzí, tj. ekologické udržitelnosti, sociální udržitelnosti či ekonomické udržitelnosti." Pokud tedy environmentální výchova mohla být zkresleně interpretována jako výchova o životním prostředí, mưže být ESD interpretována jako výchova o ekonomické udržitelnosti.

Nově prosazovaný pojem tedy není podle Robottoma kvalitativním prínosem proti stávajícímu sloganovému systému a není zaručeno, že povede k pozitivním změnám v oblasti environmentálně orientované výchovy. Jeho prosazování může odůvodnit činnost řady institucí a čerpání značných finančních zdrojů bez reálných a dlouhodobých dopadů.

\section{Nový přístup: pluralistická tradice}

Podle Östmana s Öhmanem (2007) je možné odlišit tři různé tradice environmentální výchovy v euroamerickém okruhu. První z nich, faktografická, se vyvíjí od šedesátých let 20. století a dominuje $v$ letech sedmdesátých. Typický pro ni byl dưraz na př́rodní vědy, centrální postavení učitele, znalosti předávané jako fakta a pasivní role studentů. V osmdesátých letech se jako určitá alternativa objevil proud normativní, který do environmentální výchovy více zapojoval i společenské vědy, téma budoucnosti, hodnoty, globální dimenze vztahů, aktivní roli studentů, kteří se mohli spolupodílet na plánování výuky. Od poloviny devadesátých let je pak podle nich patrný posun od normativní tradice k tradici pluralistické, reflektující myšlenky udržitelného rozvoje. $V$ té je kladen důraz na rovnováhu mezi ekonomickými, sociálními a ekologickými perspektivami ve výuce, výuka je integrovaná, spojuje lokální, regionální i globální dimenzi, žáci se učí kriticky zkoumat jednotlivá stanoviska a sami pod dohledem učitele formulují cíle své výuky.

To koresponduje s pojetím environmentální výchovy reprezentované Finnem Mogensenem (2004), podle kterého je environmentální výchova především výchovou o konfliktech zájmů o využívání území mezi různými skupinami. Výchova by proto podle něj měla být soustředěna především na rozvíjení akčních kompetencí žáků.

Důležitým rysem pluralistického přístupu je podle Öhmana (2007) také jeho hodnotová neutrálnost. Normativní tradice podle něj upadají kvůli svým východiskưm v určitých (proenvironmentálních) hodnotách do nebezpečí indoktrinace a omezení prostoru pro vyjednávání o problémech životního prostředí. Na druhé straně, rizikem pluralistického přístupu je etický relativismus, podle kterého je každé řešení "stejně dobré".

To na druhé straně není v rozporu s myšlenkami demokracie, ve které podle jeho názoru jde spíše než o sjednocování o konsensus o pluralitu a rưznost př́ležitostí. Pluralistická tradice tak odpovídá požadavkům demokratické výchovy a je také přirozeným východiskem pro výchovu k udržitelnému rozvoji, ve které "je škola chápána jako jedna $z$ částí společnosti, ve které mohou být v probíhajících otevřených diskusích hodnotové soudy o naší budoucnosti demonstrovány, promýšleny či vyměňovány ... Za druhé to znamená, že hodnoty udržitelného rozvoje se stávají předmětem stálých diskusí, ve kterých jsou myšlenky související s udržitelností a kompromisy, které musíme dělat, neustále přezkušovány, spíše než brány na podporu předem daných idejí o tom, co vytváří udržitelnou společnost. Namísto toho, aby se stal fixním cílem, udržitelný rozvoj se zde stává střelkou kompasu ukazující cestu k budoucímu rozvoji."

\section{Nový přístup: radikálně transformativní pojetí}

Radikálnější alternativu k Öhmanově chápání ESD představuje např. Stephen Sterling (2002). Podle něj jsou přístupy označované jako "výchova k udržitelnému rozvoji" či "environmentální výchova" svázány rámcem "mechanistického vzdělávacího 
paradigmatu, který může mít pouze omezený úspěch." (Sterling, 2002, s.11) Potřebná změna je přechod od transmisivního učení k transformativnímu, které vychází z transformace výchovně vzdělávacího paradigmatu. Tím je ekologický, participativní světový názor, který "může být interpretován jako celostní systémové myšleni”. Sterling toto pojetí označuje jako „udržitelná výchova" (sustainable education). Udržitelná výchova podle něj zdůrazňuje proces, kvalitu učení, participaci a posun směrem k "výchově jako změně / výchově jako udržitelnosti (education as sustainability)", ve které je nedílnou částí procesu i celé prostředí školy. Př́kladem mohou být školy zapojené do Hnutí za výchovu v lidském měřítku (Human Scale Education movement): Malá škola v Hartlandu zdůrazňuje hodnoty komunity, spirituality, participace. Škola odebírá bioprodukty od místních farmářů a fairtradové výrobky, užívá přírodní materiály, na pozemcích je ponechána divoká príroda. Kromě učitelư učí ve škole i místní řemeslníci. Škola má maximálně čtyřicet žáků a udržuje tak výchovu a vztahy v malém měřítku.

Podobné myšlenky se objevují i v přístupech označovaných jako „lokálně orientovaná výchova" (place-based education) (Sobel, 2005) nebo výchova k ekogramotnosti (Stone \& Barlow, 2005; Capra, 1999). Důraz se klade na propojení školy s místní komunitou, zaměření na lokální fenomény, "organickou perspektivu", "ekospravedlnost" (eco-justice), atd. (Van Kannel-Ray, 2006)

\section{Nové přístupy: srovnání}

Oba přístupy se v řadě ohledů shodují, v některých se ale významně liší. Oba kladou důraz na participaci studentů, rozvíjení akčních kompetencí, místní kontext a sepjetí $s$ komunitou či projektově orientovanou výuku. Podstatný rozdíl je ale v hodnotových základech obou směrů. Ačkoliv je výchova k udržitelnému rozvoji (ESD) v Öhmanově koncepci prezentována jako hodnotově neutrální, bylo by přesnější uvést, že vychází z demokratických hodnot a postojů, jako je aktivní přístup ke světu a respekt k různosti názorů.

Transformativní pojetí udržitelné výchovy (SE) jde v tomto ohledu dál. Přestože i Sterling zdůrazňuje její kritické, dekonstruktivistické základy, (Sterling, 2001, s. 84) představuje samotné zaměření SE jako "výchovy pro změnu" explicitní přihlášení se k hodnotám, které souvisí s paradigmatem udržitelného života. Těmi jsou zejména hodnota ekosociální komunity, úcta k životu a smysl pro jeho krásu (Orr, 2006, 1994).

Koncept SE tedy implicitně předpokládá, že „ekologicky gramotné" názory na životní prostředí, tj. názory vycházející z porozumění vztahům mezi námi a naší ekosociální komunitou, respektující život a jeho tajemství jsou vyzrálejší a tedy správnější, což je $\checkmark$ rozporu s Öhmanovým pojetím ESD. Důrazem na člověka a dohodu mezi lidmi je ESD v Öhmanově či Mogensenově pojetí implicitně antropocentricky orientovaným přístupem, zatímco SE se svým zdưrazňováním hodnoty ekosociálního společenství staví spíše na pozice eko/bio - centrické etiky.

Öhmanovo pojetí ESD velmi pečlivě reaguje na obavy vyjádřené McClarenem: je neideologické, učí vytvářet možnosti a vybírat z nich. Na druhé straně mưže být nazíráno jako mělký, antropocentrický přístup k výchově. Sterlingovo, Orrovo či Caprovo pojetí SE je naproti tomu mnohem bližší van Matreho či hlubinně ekologickým názorưm na výchovu, pravděpodobně ale může být vystaveno kritice za jistý stupeň indoktrinace.

\section{Závěr}

Koncept výchovy k udržitelnému rozvoji, prosazovaný vládními a mezinárodními institucemi, byl v prostředí odborné komunity zaměřené na environmentální výchovu přijat značně rozporným způsobem. Kromě odmítnutí a zpochybnění byl nově redefinován a naplněn přinejmenším dvěma rưznými obsahy. Jedním je koncept eticky neutrálního pluralistického učení, zdůrazňujícího význam akčních kompetencí, participace a kritického 
dialogu při slad’ování různých názorů na využívání území. Druhým jsou radikálnější bio/eko- centrické prístupy požadující celostní reformu škol v duchu systémového ekologického paradigmatu.

Strategie a dokumenty, vydávané institucemi na podporu a prosazování výchovy k udržitelnému rozvoji, se budou muset vyrovnat s následujícími otázkami:

- Jaký je vztah výchovy k udržitelnému rozvoji k environmentální výchově? Je navrhovaná koncepce chápána jako prohloubení určitých aspektů environmentální výchovy, její nahrazení nebo je zde chápána jako paralelní př́stup k environmentální problematice? Jaký je její vztah ke stávajícím kurikulárním dokumentům?

- Jakým způsobem použitý sloganový systém zaručuje praktické implikace navrhovaných opatření? $\vee$ čem jsou tato navrhovaná opatření inovativní proti stávající praxi? Jaký evaluační systém bude použit?

- Na který z proudů hlásících se $\mathrm{k}$ výchově $\mathrm{k}$ udržitelnému rozvoji / výchově k udržitelnosti, atd. strategie navazuje? Je jejím cílem podpora pluralistického chápání výuky jako rozvíjení akčních kompetencí nebo usiluje o radikální systémovou reformu škol, včetně souvisejících institucionálních změn (tj. např. prostředky na zvýšení počtu škol pro menší počet žáků, ekologizaci jejich provozu, atd.)? Jaké konkrétní typy projektů budou na základě strategie podporovány?

Přijaté strategie by patrně měly reflektovat společné motivy, ve kterých se jednotlivé názory na výchovu k udržitelnému rozvoji shodují. Měly by zdứrazňovat význam místního kontextu ve výchově, rozvíjení akčních kompetencí a kritického myšlení. Na druhé straně by neměla jít cestou sestavování obsahově závazného kurikula a neměla by zvýhodňovat ekologickou, ekonomickou ani sociální složku udržitelnosti nad ostatní.

\section{Literatura}

- Capra, F. . Ecology and Community. Retrieved from http://www.ecoliteracy.org/publications/pdf/community.pdf

- Capra, F. (1999). Ecoliteracy. The Challenge for Education in the Next Century. Liverpool Schumacher Lectures, Retrieved from http://www.ecoliteracy.org

- McClaren, M. (1993). Education, not ideology. Green Teacher / Education for Planet Earth, 35, 17-18.

- McKeown, R. (2002). Education for Sustainable Development Toolkit. Knoxville: Energy, Environment and Resource Center University of Tennessee. Retrieved from http://www.esdtoolkit.org

- van Kannel-ray, N. (2006). Guiding Principles and Emergin Practices for Environmentally Sustainable Education. Curriculum and Teaching Dialogue, 8(1/2), 113-123.

- $\quad$ van, S., Matre, \& Farber, L. (2005). Rangers of the Earth. Greenville: The Institute for Earth Education.

- Mogensen, F. . Environmental education - development and evaluation. : The Royal Danish School of Educational Studies. Retrieved from http://nibis.ni.schule.de/ beckmann/health/booklet/ee start.htm

- Öhman, J. (2007). Compromises and democratic responsibility. in ESD. Durban: World Environmental Education Congress.

- Orr, D. W. (1994). Earth in Mind. On Education, Environment, and the Human Prospect. Washington: Island Press. 
- Orr, D. W. . A Sense of Wonder. . Retrieved from http://www.ecoliteracy.org

- Östman, L., \& Öhman, J. (2007). Selective traditions within Environmental Education. Durban: World Environmental Education Congress.

- Robottom, I. (2007). Re-badbed Environmental Education: Is ESD more than just a slogan? Southern African. Journal of Environmental Education. 2007, 40, 90-96.

- Slocombe, D. S. (1993). Getting to the heart of sustainable development. Green Teacher. Education for Planet Earth, 35, 10-12.

- Tbilisi Declaration (1977). . Retrieved from http://www.gdrc.org/uem/ee/tbilisi.html

- Sterling, S. (2001). Sustainable education. Re-visioning Learning and Change. Bristol: The Schumacher Society.

- Sobel, D. (2005). Place-Bbased Education: Connecting Classrooms \& Communities. Barrington: The Orion Society.

- Stone, M. K., \& Barlow, Z. (2005). Ecological Literacy. Educating Our Children for a Sustainable World. San Francisco: Sierra Club Books.

- UNESCO. Education for Sustainable Development (2004). . Retrieved from http://portal.unesco.org/education 
Časopis Envigogika vydává Centrum pro otázky životního prostředí UK. Vývoj časopisu je podpořen projektem OP VK Mezioborová sít udržitelného rozvoje.

Více najdete na internetových stránkách projektu mosur.czp.cuni.cz
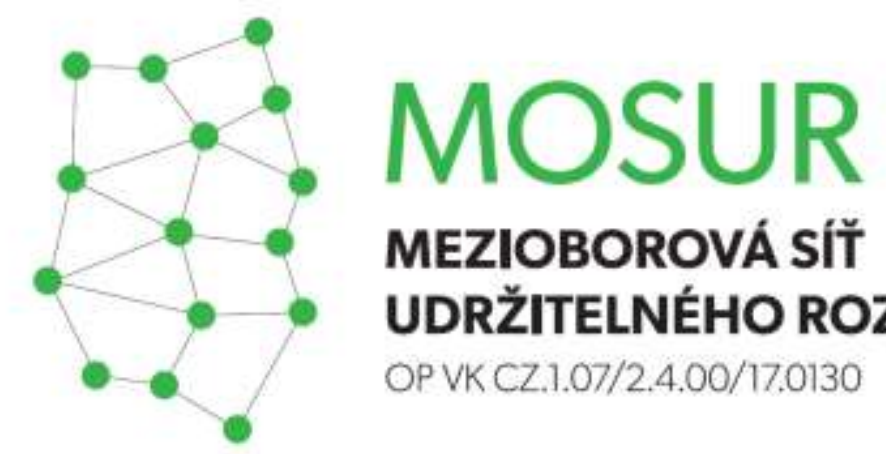

\section{MEZIOBOROVÁ SÍT} UDRŽITELNÉHO ROZVOJE

OP VK CZ.1.07/2.4.00/17.0130
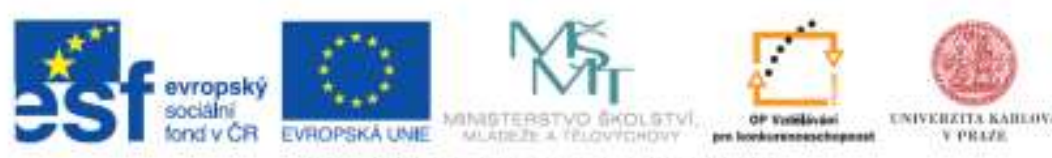

INVESTICE DO ROZVOJE VZDELAVANI 